\title{
Antigenic Components of the Cell Wall of Streptococcus salivarius
}

\author{
By ELIZABETH A. MONTAGUE* AND K. W. KNOX \\ The Institute of Dental Research, The United Dental Hospital, \\ Surry Hills, New South Wales, Australia 2010
}

(Accepted for publication 28 June 1968)

\begin{abstract}
SUMMARY
A survey of 9I strains of Streptococcus salivarius showed that 72 could be classified as type I or II. Only type I strains reacted with group $\mathrm{K}$ antiserum. The component responsible for type specificity is a cell-wall polysaccharide composed in each case of galactose, glucose, rhamnose and a trace of glucosamine. However, differences in polysaccharide structure are indicated by differences in the rate of release of soluble carbohydrate by dilute acid. Soluble cell-wall products were obtained by digesting wall with a Streptomyces enzyme preparation and used for serological studies. Galactose was the most effective monosaccharide inhibitor of both type I and type II precipitation. Further investigation suggested that type I specificity depends on the grouping $O$ - $\beta$-D-galactopyranosyl-(I $\rightarrow 6)$-D-galactose.
\end{abstract}

\section{INTRODUCTION}

Most strains of streptococci and lactobacilli can be classified into groups by the Lancefield (1933) technique of extraction of serologically reactive material with hot dilute acid. Strains of Streptococcus salivarius do not form a single group by this criterion, but have been grouped together because of their ability to form a levan when grown on sucrose agar (Williams, 1956). Sherman, Niven \& Smiley (1943) prepared antisera to a number of strains of $S$. salivarius and found that $40 \%$ of strains tested were serologically related. Mirick, Thomas, Curnen \& Horsfall (1944), by using aqueous and alkaline extracts of encapsulated organisms, divided the strains into two types, I and II. Horsfall (195I) suggested that specific capsular polysaccharides, as distinct from levans, were responsible for serological reactivity and identified at least six serological types. More recent studies have shown that extracts from certain strains of $S$. salivarius react with antisera to group K streptococci (Williams, 1956; Stewart \& McKeever, I963), and that antiserum to type I S. salivarius reacts with a type antigen from some group F streptococci (Willers, Ottens \& Michel, 1964). The present report describes the isolation and characterization of serologically reactive cell-wall components from strains of $S$. salivarius.

\section{METHODS}

Strains of Streptococcus salivarius. A type I strain, designated Streptococcus hominis, NCTC 8606, was obtained from the National Collection of Type Cultures, Colindale, London, and a type II strain, designated ATCC I34I9, from the American Type Culture

* Dental Board of New South Wales Research Officer; formerly Elizabeth A. Hall. 
Collection. Strain $3 \mathrm{I}$ was provided by the School of Microbiology, University of Melbourne. A further 9I strains of S. salivarius were isolated from human saliva; one chosen for more detailed investigation was designated HCS. These strains were identified by a mucoid growth on agar containing $5 \%(\mathrm{w} / \mathrm{v})$ sucrose $+0.00025 \%(\mathrm{w} / \mathrm{v})$ crystal violet $+0.001 \%(\mathrm{w} / \mathrm{v})$ potassium tellurite $+5 \%(\mathrm{v} / \mathrm{v})$ horse serum; identification was confirmed by a series of fermentation reactions kindly performed by $\mathrm{Mr} \mathrm{H}$. C. Spies of this Institute.

Culture conditions. Cultures for the preparation of cell walls, for inoculation into rabbits and for acid extraction of serologically reactive material were grown at $37^{\circ}$ for $\mathrm{I} 8 \mathrm{hr}$ in Trypticase-Soy broth (Baltimore Biological Laboratories, Baltimore, Md., U.S.A.). For testing capsule production, organisms of strain NCTC 8606 were grown in I 1. of each of the following media: Trypticase-Soy broth (referred to as M I), ToddHewitt broth (M 2), and the diffusible components of Todd-Hewitt broth (M 3). After I $8 \mathrm{hr}$ at $37^{\circ}$, organisms were removed by centrifugation, washed twice with $0.85 \%$ (w/v) $\mathrm{NaCl}$ and negatively stained with Indian ink to detect capsules. The culture fluid and washings were retained.

Cell-wall preparation. Organisms were harvested by centrifugation, washed, and shaken with Ballotini no. 13 glass beads in the attachment for the International centrifuge (Shockman, Kolb \& Toennies, 1957), until the Gram reaction indicated that at least $95 \%$ disintegration had been effected. Following differential centrifugation to remove unbroken organisms and soluble cytoplasmic contents, the crude cell-wall preparation was heated for $30 \mathrm{~min}$. at $100^{\circ}$, and incubated overnight at $37^{\circ}$ with trypsin + ribonuclease (Cummins \& Harris, 1956). The preparation was washed three times with $0.05 \mathrm{M}$-tris $+\mathrm{HCl}$ buffer ( $\mathrm{pH}_{7} \cdot 8$ ), then with water until free from material with absorption maxima at $260 \mathrm{~m} \mu$ (nucleic acid) and $280 \mathrm{~m} \mu$ (protein), and dried from the frozen state.

Soluble cell-wall fractions. In preliminary experiments preparations of cell wall from strains NCTC 8606, ATCC 134I9, 3 I and HCS were incubated with lysozyme and the muralytic enzyme(s) extracted from the growth medium of Streptomyces albus (McCarty, 1952). Lysozyme had no detectable action, whereas the Streptomyces enzyme caused a partial dissolution. Consequently cell-wall preparations from each of the above four strains were suspended in $0.05 \mathrm{M}$-tris $+\mathrm{HCl}$ buffer $(\mathrm{pH} \mathrm{7.8)}$ ) to a final concentration of $0.3 \%(\mathrm{w} / \mathrm{v})$, and $0.05 \%(\mathrm{v} / \mathrm{v})$ of Streptomyces enzyme preparation added. After $44 \mathrm{hr}$ at $37^{\circ}$, the extinction at $600 \mathrm{~m} \mu$ had fallen to $10 \%$ of its original value. Cell-wall residue was removed by centrifugation and the supernatant solution fractionated with $\left(\mathrm{NH}_{4}\right)_{2} \mathrm{SO}_{4}$ (Knox, 1963$)$; the material precipitated by $70 \%$ saturation was designated Fraction A, and that remaining in solution Fraction $\mathrm{B}$.

Serology. Antisera to strains NCTC 8606, ATCC I3419, 3I and HCS were prepared by the procedure used by Knox \& Brandsen (1962), with and without the use of adjuvant. Antiserum to group $\mathrm{K}$ streptococci was obtained from Burroughs Wellcome, United Kingdom.

Acid extracts of organisms were prepared by the method of Lancefield (I933). Antibody reactions were detected by the precipitin ring test and its micro-modification in capillaries (Swift, Wilson \& Lancefield, 1943), by double diffusion in agar (Ouchterlony, I953), and by quantitative estimation of the precipitate formed (Heidelberger \& MacPherson, 1943).

Carbohydrates. $O-\beta$-D-Glucopyranosyl- $(\mathrm{I} \rightarrow 6)$-D-galactose was prepared as 
described previously (Knox, 1965). Professor K. Freudenberg (University of Heidelberg, Germany) kindly provided $O-\beta$-D-galactosyl-(I $\rightarrow 6)$-D-galactose; and $O$ - $\beta$-D-glucosyl-(I $\rightarrow 3)$-D-galactose (solabiose) was the generous gift of Professor R. Kuhn (Max-Planck Instituit, Heidelberg, Germany). All other carbohydrates were commercial preparations.

Paper chromatography. The following solvents were used: $A$, ethyl-acetate + pyridine + water $(\mathrm{IO}+4+3$, by vol.); $B$, butan-I-ol + pyridine + water $(6+4+3$ by vol.); $C$, butan-2-one + acetic acid + water saturated with boric acid $(9+\mathrm{I}+\mathrm{I}$, by vol.; Rees \& Reynolds, I958); $D$, propan-I-ol + ammonia + water $(6+3+\mathrm{I}$, by vol.); $E$, butan-I-ol + acetic acid + water $(6+\mathrm{I}+2$, by vol.) followed by $F$, pyridine + water $(4+I, v / v)$ along the perpendicular axis for separation of amino acids. Chromatograms were developed in a descending direction on Whatman no. $3 \mathrm{MM}$ or Whatman no. I paper. Sugars were detected with alkaline silver nitrate (Trevelyan, Procter \& Harrison, 1950), alcohols by a modification of this method (Frahn \& Mills, I959), hexosamines with alkaline acetylacetone and Ehrlich's reagent (Partridge, 1948), and amino acids with ninhydrin $(0.2 \%)$ in acetone.

Paper electrophoresis. Paper electrophoresis was done on strips of Whatman no. $3 \mathrm{MM}$ paper, $64 \mathrm{~cm}$. long, between horizontal glass plates, $\mathrm{I} \cdot 4 \mathrm{~cm}$. thick, in $0.05 \mathrm{M}-$ sodium tetraborate (Frahn \& Mills, 1959); a potential difference of 800-900 V was applied for $5 \mathrm{hr}$; cooling was done by doing the experiments in a refrigerator. Carbohydrates were detected with a modified alkaline silver nitrate reagent (Frahn \& Mills, 1959).

Analytical methods. Hexose was estimated by the primary cysteine $+\mathrm{H}_{2} \mathrm{SO}_{4}$ method (Dische, 1955), glucose with glucose oxidase (Huggett \& Nixon, 1957) and galactose with galactose oxidase (Roth, Segal \& Bertoli, I965). Rhamnose was estimated by the method of Dische \& Shettles (1948) as modified by Gibbons (1955).

Hydrolysis before the estimation of hexosamines was done with $4 \mathrm{~N}-\mathrm{HCl}$ at $100^{\circ}$ for $\mathrm{I} \mathrm{hr}$. Muramic acid was separated from glucosamine and galactosamine on charcoal + celite columns by the method of J. T. Park, as described by Perkins \& Rogers (I959); the hexosamines were then estimated by the method of Rondle \& Morgan (1955). Galactosamine was estimated by the method of Cessi \& Serafini-Cessi (1963).

Borohydride reduction. Reduction of oligosaccharides (approximately $3 \mu$ moles in I.0 ml.) was effected with sodium borohydride ( $25 \mathrm{mg}$.). After $4 \mathrm{hr}$ at room temperature, the solution was neutralized, de-ionized with Bio-Deminrolit (carbonate form; The Permutit Co. Ltd.), and repeatedly evaporated to dryness from methanol to remove residual borate. After hydrolysis for $2 \mathrm{hr}$ in $2 \mathrm{~N}-\mathrm{HCl}$ at $100^{\circ}$ the products were identified by chromatography in solvent $C$.

Periodate oxidation. Oxidation of oligosaccharides was done by a modification of the method of Kabat \& Mayer (196I). The carbohydrate solution ( $1 \cdot 0 \mathrm{ml}$. containing approximately $0.3 \mu$ mole) was mixed with $0.5 \mathrm{ml}$. of $0.004 \mathrm{M}$-sodium periodate and allowed to stand in the dark at room temperature $\left(20^{\circ}\right)$. At suitable intervals, $0 \cdot \mathrm{I} \mathrm{ml}$. of solution was diluted to $\mathrm{I} \cdot 0 \mathrm{ml}$. and the extinction read at $225 \mathrm{~m} \mu$; the end-point occurred after 3-4 hr, when no further uptake of periodate was apparent. 


\section{RESULTS}

\section{Composition of cell components}

Analysis of cell-wall products. Acid hydrolysates of the cell-wall preparations from the four strains of Streptococcus salivarius were examined by paper chromatography for component carbohydrates; glucose, galactose, rhamnose, glucosamine and muramic acid were detected. The results of quantitative analysis are given in Table I. Galactosamine was not detected by paper chromatography, nor by the specific method for its estimation (Cessi \& Serafini-Cessi, 1963). Table I also contains information on the yields and composition of the preparations designated Fraction B; these preparations were obtained in each case by ammonium sulphate fractionation of the products obtained by the action of the Streptomyces enzyme on cell-wall preparations of the appropriate strain. Glucose, galactose and rhamnose were major components of both the cell wall and Fraction B, presumably being components of a polysaccharide or polysaccharides attached to the mucopeptide. Glucosamine and muramic acid are known components of mucopeptide, but the present results do not exclude the possibility that glucosamine may also be a component of the polysaccharide(s). Qualitative amino acid chromatography indicated that only those amino acids were present which might be expected to be components of the mucopeptide, namely; lysine, glutamic acid, aspartic acid and alanine.

Tests for the possible formation of capsule. Organisms of strain NCTC 8606 grown in media $\mathrm{M}_{1}, \mathrm{M}_{2}$ and $\mathrm{M}_{3}$ did not possess a capsule demonstrable with indian ink. However, because of the suggested presence of a type-specific capsule (Mirick et al. 1944) other tests were done. Organisms were grown in each of the three media, washed and dried from the frozen state. Each of the culture fluids was dialysed, centrifuged and retained for carbohydrate analysis. The yields of organisms per litre of culture fluid were (dry wt): $200 \mathrm{mg}$. for M I, I40 mg. for M2, $160 \mathrm{mg}$. for M3. Batches of organisms from $I$ l. culture fluid were then subjected to two extraction procedures: shaking at room temperature in $2.5 \%(\mathrm{w} / \mathrm{v}) \mathrm{NaCl}$ for $2 \mathrm{hr}$ (Knox \& Hall, 1964), and standing in water at room temperature overnight (Mirick et al. 1944). The dialysed culture fluids and the extracts were examined quantitatively for the presence of hexose and rhamnose, which had previously been shown to be components of the cell-wall polysaccharide. In no case did the amount of these components exceed $2 \%$ of that present in the corresponding organisms. The culture fluids were also tested for ketose with Seliwanoff's reagent; the results were negative, indicating that levan was not present.

Release of carbohydrate from cell walls by mild acidhydrolysis. During the investigation of the serological properties of cell extracts prepared by the Lancefield (I933) method, it was observed that those from type I stains gave a strong reaction, whereas those from type II strains gave a weak, although positive, reaction. It was shown by Knox $\&$ Hall ( $1965 b)$ that when cell walls of Lactobacillus casei were subjected to mild acid hydrolysis, the linkage between the specific polysaccharide and the mucopeptide was hydrolysed. Since many streptococci yield a similar serologically reactive polysaccharide, the rate of release of carbohydrate from Streptococcus salivarius cell wall by dilute acid was examined. The conditions used were the same as those previously found to be satisfactory for $L$. casei, namely, heating in $0 \cdot \mathrm{I} \mathrm{N}-\mathrm{H}_{2} \mathrm{SO}_{4}$ at $60^{\circ}$. Suspensions of cell wall (I mg./ml.) from each of the four strains were heated for appropriate 
periods, cooled, centrifuged, and the hexose and rhamnose content of the supernatant fluid determined. The results obtained at three selected intervals are compared in Table 2; they are expressed as \% of the total amount of hexose and rhamnose in the appropriate cell-wall preparation. The results showed that although the rate of rhamnose release was similar for each strain, the type I strains (NCTC 8606 and 3I) gave a much more rapid release of hexose; in $\mathrm{I} h \mathrm{hr}$ this was comparable with the amount released from Lactobacillus casei cell wall under the same conditions.

To obtain the polysaccharide component of the cell wall with minimal degradation, preparations of cell walls ( $500 \mathrm{mg}$.) from strains NCTC 8606 and ATCC 13419 were heated in $0.1 \mathrm{~N}-\mathrm{H}_{2} \mathrm{SO}_{4}$ at $60^{\circ}$ for six $30 \mathrm{~min}$. periods. After each period, the suspension was centrifuged, the supernatant fluid removed and the residue re-heated in the original volume. The pooled supernatant solutions were dialysed, and total carbohydrate determined on the diffusible and indiffusible fractions. The analyses indicated that approximately $94 \%$ of the carbohydrate was indiffusible. The indiffusible fractions were dried from the frozen state; the yield from NCTC 8606 was $192 \mathrm{mg}$. and from ATCC 13419 was $88 \mathrm{mg}$. The components of each preparation were galactose, glucose, rhamnose and a trace of glucosamine (Table 1 ).

\section{Table I. Analyses of cell-wall components of Streptococcus salivarius}

Procedures for the preparation of the fractions are given in the text. Results are expressed as \% dry weight of the fraction; - analysis not performed.

\begin{tabular}{|c|c|c|c|c|c|c|c|}
\hline \multirow[b]{2}{*}{ Strain } & \multirow[b]{2}{*}{ Fraction } & \multirow{2}{*}{$\begin{array}{l}\text { Yield } \\
(\% \text { of } \\
\text { wall })\end{array}$} & \multicolumn{5}{|c|}{ Analyses } \\
\hline & & & Glucose & Galactose & Rhamnose & $\begin{array}{l}\text { Glucos- } \\
\text { amine }\end{array}$ & $\begin{array}{c}\text { Muramic } \\
\text { acid }\end{array}$ \\
\hline NCTC 8606 & $\begin{array}{l}\text { Wall } \\
\text { B* }^{*} \\
\text { Polysac. } \dagger \\
\text { Residue } †\end{array}$ & $\begin{array}{l}30 \\
38 \\
40\end{array}$ & $\begin{array}{r}14 \cdot 4 \\
23 \cdot 5 \\
26 \cdot 0 \\
7 \cdot 1\end{array}$ & $\begin{array}{r}17 \cdot 0 \\
10 \cdot 8 \\
37 \cdot 0 \\
7 \cdot 0\end{array}$ & $\begin{array}{l}17 \cdot 5 \\
29 \cdot 0 \\
23 \cdot 5 \\
12 \cdot 0\end{array}$ & $\begin{array}{l}7 \cdot 0 \\
6 \cdot 7 \\
2 \cdot 5 \\
-\end{array}$ & $\begin{array}{c}9 \cdot 2 \\
6 \cdot 6 \\
- \\
-\end{array}$ \\
\hline $3 \mathbf{I}$ & $\begin{array}{l}\text { Wall } \\
\text { B }^{*}\end{array}$ & 50 & $\begin{array}{l}17 \cdot 5 \\
26 \cdot 5\end{array}$ & $\begin{array}{r}9 \cdot 2 \\
19.9\end{array}$ & $\begin{array}{l}21 \cdot 0 \\
32 \cdot 0\end{array}$ & $\begin{array}{r}10 \cdot 0 \\
6.0\end{array}$ & $\begin{array}{l}9.0 \\
7.0\end{array}$ \\
\hline ATCC 13419 & $\begin{array}{l}\text { Wall } \\
\text { B* }^{*} \\
\text { Polysac. } \dagger \\
\text { Residue } \dagger\end{array}$ & $\begin{array}{l}. \\
20 \\
18 \\
26\end{array}$ & $\begin{array}{r}13.5 \\
18.5 \\
24.9 \\
5.1\end{array}$ & $\begin{array}{r}20 \cdot 0 \\
6 \cdot 6 \\
35 \cdot 7 \\
12 \cdot 5\end{array}$ & $\begin{array}{l}21 \cdot 0 \\
32 \cdot 0 \\
22 \cdot 5 \\
10 \cdot 5\end{array}$ & $\begin{array}{l}8 \cdot 4 \\
8 \cdot 2 \\
2 \cdot 0 \\
-\end{array}$ & $\begin{array}{c}9 \cdot 0 \\
7 \cdot 2 \\
- \\
-\end{array}$ \\
\hline HCS & $\begin{array}{l}\text { Wall } \\
\text { B }^{*}\end{array}$ & 30 & $\begin{array}{l}10 \cdot 0 \\
19.0\end{array}$ & $\begin{array}{r}5.6 \\
14.8\end{array}$ & $\begin{array}{l}177^{\circ} \\
35^{\circ} 0\end{array}$ & $\begin{array}{l}10 \cdot 0 \\
14.0\end{array}$ & $\begin{array}{l}9 \cdot 5 \\
5 \cdot 0\end{array}$ \\
\hline
\end{tabular}

* Purified soluble products obtained from cell walls treated with Streptomyces enzyme.

† Polysaccharide extracted from cell walls by dilute acid, and residue remaining after prolonged extraction.

Cell walls were heated for a further $16 \mathrm{hr}$, and the residues then recovered, washed and freeze-dried. The residue from each strain still contained significant amounts of polysaccharide (Table I).

\section{Serological examination of soluble cell components}

A serological survey of 9I strains of Streptococcus salivarius isolated from human saliva showed that the majority could be classified as either type I or type II : (a) 39 strains reacted with type I antiserum only; (b) 33 strains reacted with type II antiserum only; 
(c) I I strains reacted with both antisera; (d) 8 strains reacted with neither antiserum. A reaction with group $\mathrm{K}$ antiserum was given by 38 strains in category $(a)$ and by all the strains in category $(c)$, i.e. 49 of the 50 strains that reacted with type I antiserum.

Table 2. Streptococcus salivarius. Amounts of hexose and rhamnose released on heating cell walls in $\mathrm{O} \cdot \mathrm{I} \mathrm{N}-\mathrm{H}_{2} \mathrm{SO}_{4}$ at $60^{\circ}$

Results are expressed as \% total amount present in the wall.

S. salivarius strain

$\begin{array}{ccccccccc}\text { Time } & \overbrace{\text { (hr) }}^{\text {Hexose }} & \text { Rhamnose } & \overbrace{\text { Hexose }}^{\text {NCTC 8606 }} & \text { Rhamnose } & \overbrace{\text { Hexose }}^{\text {Rhamnose }} & \text { Res } & \overbrace{\text { Hexose }}^{\text {Rhamnose }} \\ \text { I.0 } & 52 & 29 & 37 & 27 & 7 & 24 & \text { I2 } & \text { I3 } \\ 4 \cdot 0 & 75 & 37 & 68 & 40 & 19 & 35 & 22 & 29 \\ \text { I6.0 } & 87 & 68 & 79 & 60 & 40 & 58 & 33 & 45\end{array}$

Strain $3 \mathrm{I}$ cross-reacted with antiserum to strain NCTC 8606 but not with antiserum to strain ATCC 13419, and was therefore concluded to be a type I strain. Lancefield extracts of whole organisms were shown to contain three serologically reactive components when tested against homologous antiserum, group $\mathrm{K}$ antiserum or antiserum to strain NCTC 8606. Lancefield extracts of cell wall and Fraction B from strain 3I, as well as Fraction B from strain NCTC 8606, contained a single component which appeared to correspond to the strongest of the three bands obtained with extracts of whole organisms.

Strain HCS cross-reacted with antiserum to ATCC 13419 (type II) but not with antiserum to strain NCTC 8606 (type I) and was therefore concluded to be a type II strain. A comparison of Lancefield extracts of whole organisms, cell walls and Fraction B by the Ouchterlony method indicated the presence of the same three components, one major and two minor, in each preparation; similar results were obtained with homologous antiserum and with antiserum to ATCC 13419 .

Inhibition of precipitin reaction by component carbohydrates. The ability of glucose, galactose and rhamnose to inhibit the precipitin reaction between preparations of Fraction B from strains HCS, 3I and NCTC 8606 and homologous antiserum was examined. Antiserum ( $0.2 \mathrm{ml}$.) was mixed with $25 \mu$ moles of monosaccharide in a final volume of $0.5 \mathrm{ml}$. After $\mathrm{I} \mathrm{hr}$ at $37^{\circ}$ an appropriate amount of Fraction B was added, and the amount of precipitate formed on subsequent standing determined (Heidelberger \& MacPherson, 1943). The results, summarized in Table 3, show that galactose was the most effective inhibitor in each case.

Since the serological reaction with Fraction B from type I strains appeared to involve only one antigenic component, further studies were made of the specificity of the reaction. Cell walls from type I strains were subjected to mild acid hydrolysis and the oligosaccharide components separated (see below). Three disaccharides were obtained, but only one contained a non-reducing galactose residue, viz. $O-\beta$-D-galactopyranosyl( $\mathrm{I} \rightarrow 6$ )-D-galactose; $10 \mu$ moles of this disaccharide inhibited the precipitation of Fraction B from NCTC 8606 by $37 \%$. Another product of hydrolysis was identified as $O-\beta$-D-glucopyranosyl-( $\mathrm{I} \rightarrow 6)-\mathrm{D}$-galactose. This disaccharide is responsible for the specificity of the group antigen of Lactobacillus casei, Group C (Knox \& Hall, 1965a). However, qualitative precipitin tests indicate very little, if any, cross-reaction between L. casei and Streptococcus salivarius. 
Identification of disaccharides obtained on partial hydrolysis of cell wall

Preliminary tests showed that the maximum production of oligosaccharides occurred

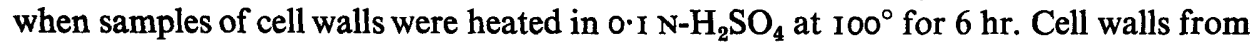
strains $3 \mathrm{I}$ and 8606 yielded products which were indistinguishable on chromatography in solvent $A$, not only with regard to mobility, but also apparently with regard to the proportion of each present. Cell wall $(275 \mathrm{mg}$.) from strain 3I was hydrolysed under the above conditions and neutralized with barium hydroxide. Oligosaccharides were separated by elution from charcoal + celite followed by preparative paper chromatography in solvent $A$, as described previously (Knox \& Hall, I965 a). Three presumptive disaccharides were obtained, the yields being calculated from the hexose content: $D_{1}, 0.4$ mg.; $D_{2}, I .5 \mathrm{mg}$; $D_{3}, 5.9 \mathrm{mg}$.

Table 3. Streptococcus salivarius. Inhibition of precipitin reaction between preparations of Fraction $B$ and homologous antiserum by 20 umoles of monosaccharide

\begin{tabular}{cl}
$\begin{array}{c}\text { Serological } \\
\text { type }\end{array}$ & \multicolumn{1}{c}{$\begin{array}{c}\text { Source of } \\
\text { Fraction II }\end{array}$} \\
I & Strain 3I \\
I & Strain NCTC 8606 \\
II & Strain HCS
\end{tabular}

Amount
$(\mu \mathrm{g}$.
20
40
20

\begin{tabular}{ccc}
\multicolumn{3}{c}{$\%$ inhibition by } \\
$\overbrace{\text { Glucose }}$ & Galactose & Rhamnose \\
7 & 40 & 20 \\
7 & 23 & 5 \\
9 & 40 & 17
\end{tabular}

Identification of compound $D_{1}$ as $O$ - $\beta$-D-galactopyranosyl-(I $\left.\rightarrow 6\right)$-D-galactose. Only one component was detected by chromatography in solvents $A\left(R_{a l c}: 0.34\right)$ and $B$ $\left(R_{G l c}: 0.39\right)$, and electrophoresis in sodium tetraborate $\left(M_{G}: 0.80\right)$. Acid hydrolysis followed by chromatography in solvents $A$ and $B$ showed galactose to be the only monosaccharide component. A $0.02 \%(\mathrm{w} / \mathrm{v})$ solution of $\mathrm{D}_{1}(0.2 \mathrm{ml}$.) was incubated with $\mathrm{I} \%(\mathrm{w} / \mathrm{v})$ almond emulsin (O. I ml.) in $0.0 \mathrm{I} \mathrm{M}$-acetate buffer $(\mathrm{pH} 5.0)$ at $37^{\circ}$ for I $8 \mathrm{hr}$. After de-ionization, paper chromatography in solvent $A$ showed that partial hydrolysis of the compound had occurred $(>50 \%$ ), to yield galactose as the only product. A sample of $D_{1}(0.3 \mu$ mole) was oxidized with sodium metaperiodate for $4 \mathrm{hr}$. The amount of periodate consumed was 4.9 moles/mole, which is consistent with a $I \rightarrow 6$ glycosidic linkage (theoretical consumption $=5$ moles $/ \mathrm{mole}$ ). The chromatographic and electrophoretic mobilities are also consistent with a $I \rightarrow 6$ linkage. Further, compound $\mathrm{D}_{1}$ was indistinguishable from an authentic sample of $O-\beta-\mathrm{D}$ galactopyranosyl-(I $\rightarrow 6)$-D-galactose on chromatography in solvent $A$ and on electrophoresis in borate buffer.

Identification of compound $D_{2}$ as $O-\beta$-D-glucopyranosyl-( $(\mathrm{I} \rightarrow 6)-D$-galactose. Only one component was detected on chromatography in solvents $A\left(R_{G l c}: 0.39\right)$ and $B$ $\left(R_{G l c}: 0 \cdot 45\right)$, and on electrophoresis in sodium tetraborate $\left(M_{G}: 0 \cdot 70\right)$. Acid hydrolysis and almond emulsin both yielded apparently equal amounts of glucose and galactose, as detected by paper chromatography in solvent $A$. The terminal reducing sugar was determined by reduction with sodium borohydride followed by acid hydrolysis and chromatography in solvent $C$; the products were glucose and galactitol. Compound $\mathrm{D}_{2}$ was indistinguishable from $O$ - $\beta$-D-glucopyranosyl-(I $\rightarrow 6$ )-D-galactose (Knox, 1965) on chromatography in solvents $A$ and $B$, and on electrophoresis in sodium tetraborate. 
Identification of compound $D_{3}$ as $O$ - $\beta$-D-glucopyranosyl-(I $\left.\rightarrow 3\right)$-D-galactose. This was the major product of acid hydrolysis; only one compound was detected on electrophoresis in sodium tetraborate $\left(M_{G}: 0.48\right)$ and chromatography in solvents $A$ and $B$ $\left(R_{\theta l o}: 0.56,0.59\right.$, respectively). Acid hydrolysis and almond emulsin ( $100 \%$ hydrolysis) both yielded apparently equal amounts of glucose and galactose, as detected by chromatography in solvent $A$. When acid hydrolysis was preceded by reduction with sodium borohydride, the products detected were glucose and galactitol. Disaccharide $\mathrm{D}_{3}$ consumed 2.8 moles/mole of sodium metaperiodate, consistent with a $\mathrm{I} \rightarrow 2$ or a I $\rightarrow 3$ glycosidic linkage (theoretical consumption $=3 \mathrm{moles} / \mathrm{mole}$ ). The possibility of a $\mathrm{I} \rightarrow 2$ linkage was excluded since compound $\mathrm{D}_{3}$ formed a red formazan with triphenyl tetrazolium chloride (Wallenfels, 1950$)$. The $[\alpha]_{\mathrm{D}}^{27.5}$ of a solution of $\mathrm{D}_{3}(c: 0.17 \%)$ was $+20^{\circ} \pm 5^{\circ}$. Because of the low concentration, this value was not regarded as sufficiently accurate for identification, but is consistent with a $\beta$-linkage; the reported value for this disaccharide is $+35^{\circ}$ to $+40^{\circ}$ (Bailey, 1965 ).

\section{DISCUSSION}

In confirmation of the results of previous workers (Mirick et al. 1944; Horsfall, I95I; Williamson, 1964), it has been found that most strains of Streptococcus salivarius can be classified as either type I or type II. The known reaction of certain strains of $S$. salivarius with group K antiserum (Williams, 1956; Stewart \& McKeever, 1963) resides exclusively with the type I strains, $98 \%$ of which reacted with group $\mathrm{K}$ antiserum. Williamson (1964), who obtained cultures from throat swabs, classified $78 \%$ of the strains as type I and $6 \%$ as type II. In the present investigation, where organisms were isolated from saliva, the corresponding values were 43 and $36 \%$. It has been shown that the tongue is the source of oral strains of $S$. salivarius (Gibbons, Kapsimalis \& Socransky, 1964), so that these differences in relative proportions may reflect the different sources of the strains.

It is apparent that cell-wall polysaccharides account for types I and II specificity. In each case the major components are galactose, glucose and rhamnose, with glucosamine (a major component of the mucopeptide) being a minor component of the polysaccharide. The finding of the three sugars in the wall of strain NCTC 8606 confirms the earlier observation by Colman \& Williams (1965). Carbohydrate analyses of cellwall preparations do not indicate differences which could account for the differences in serological specificity. However, as shown in Table 2, there are differences in the rates of release of rhamnose and hexose from cell wall preparations from types I and II organisms, and this probably reflects differences in structure.

The partial release of polysaccharide by dilute acid enabled the Lancefield procedure to be used for differentiating the two types. However, the observation that release of polysaccharide was incomplete even after $16 \mathrm{hr}$, contrasts with the results obtained with Lactobacillus casei (Knox \& Hall, I965 b) and L. fermenti (Knox \& Holmwood, 1968). With the lactobacilli, rapid release was shown to depend on the hydrolysis of a phosphodiester linkage between the polysaccharide and mucopeptide components. The results with Streptococcus salivarius suggest, therefore, that part at least of the polysaccharide component may be joined to the mucopeptide by a linkage other than a phosphodiester.

A comparison of the carbohydrate analyses of cell walls, the polysaccharide com- 


\section{Cell-wall antigens of Streptococcus salivarius}

ponents and the products obtained by Streptomyces action would also suggest that for both types I and II, the cell walls contain polysaccharide chains of varying composition. An indication that the polysaccharide fraction from type II cell wall does contain different components was provided by the results of the Ouchterlony procedure, where one major and two minor components were detected. However, with type I cell wall, the product of Streptomyces action contained only one serologically reactive component.

Owing to the impurity of the preparation, the examination of type II specificity was limited to the inhibition of the precipitin reaction by component sugars; these studies indicated that galactose was the immuno-dominant sugar. Studies on the type I specificity indicated that, in this case also, galactose was the immuno-dominant sugar, and this supported the results of Willers et al. (1964). From further studies on the inhibition by glucosides, Willers et al. (1964) concluded that the antigenic determinant was probably a $\beta-1 \rightarrow 6$-glucoside, though the ability of galactosides to inhibit the precipitin reaction was not tested. The present study enabled the inhibition by a galactoside to be examined; from the products of hydrolysis of cell wall $O-\beta$-Dgalactopyranosyl-( $\mathrm{I} \rightarrow 6)$-D-galactose was isolated and shown to be a very effective inhibitor of the precipitin reaction. It is therefore concluded that this disaccharide constitutes part of the antigenic determinant for type I specificity.

\section{REFERENCES}

BaILeY, R. W. (1965). Oligosaccharides. London: Pergamon Press Ltd.

Cessi, C. \& Serafini-CesSi, F. (1963). A method for the determination of D-galactosamine in the presence of D-glucosamine. Biochem. J. 88, 132.

Colman, G. \& Williams, R. E. O. (I965). The cell walls of streptococci. J. gen. Microbiol. 41, 375.

CUMmins, C. S. \& HaRRIs, H. (1956). The chemical composition of the cell wall in some Gram-positive bacteria and its possible value as a taxonomic character. J. gen. Microbiol. $\mathbf{4}, 583$.

DisCHE, Z. (1955). New colour reactions for determination of sugars in polysaccharides. In Methods of Biochemical Analysis. Ed. by D. Glick, vol. II, p. 313. New York: Interscience Publishers Inc.

DisChe, Z. \& SHETTLES, L. B. (1948). A specific colour reaction of methylpentoses and a spectrophotometric micromethod for their determination. J. biol. Chem. 175, 595.

Frahn, J. L. \& Mills, J. A. (I959). Paper ionophoresis of carbohydrates. I. Procedures and results for four electrolytes. Aust.J. Chem. 12, 65.

Gibbons, M. N. (1955). The determination of methylpentoses. Analyst, Lond. 80, 268.

Grbbons, R. J., Kapsimalis, B. \& Socransky, S. S. (1964). The source of salivary bacteria. Arch. oral Biol. 9, I01.

Heidelberger, M. \& MacPherson, C. F. C. (1943). Quantitative micro-estimation of antibodies in the sera of man and other animals. Science, N.Y. 97, 405.

Horsfall, F. L., JUN. (195I). Studies on non-hemolytic streptococci isolated from the respiratory tract of man. The antigenic basis for type specific reactions with Streptococcus salivarius and non-levan-forming streptococci. J. exp. Med. 93, 229.

HuggetT, A. St G. \& Nixon, D. A. (1957). Use of glucose oxidase, peroxidase and $o$-dianisidine in determination of blood and urinary glucose. Lancet ii, 368.

KABAT, E. A. \& MAYER, M. M. (I96I). Experimental Immunochemistry. Springfield, Illinois, U.S.A.: Charles C. Thomas.

KNox, K. W. (1963). Isolation of group-specific products from Lactobacillus casei and Lactobacillus casei var. rhamnosus. J. gen. Microbiol. 31, 59.

KNOX, K. W. (1965). Enzymic synthesis of $O-\beta$-D-glucopyranosyl-(I $\rightarrow 6$ )-D-galactose. Biochem. $J$. 94, 534.

KNOX, K. W. \& BRANDSEN, J. (1962). The isolation of components from the cell wall of Lactobacillus casei. Biochem. J. 85, 15. 
KNox, K. W. \& HALL, E. A. (1964). The relationship between the capsular and cell wall polysaccharides of strains of Lactobacillus casei var. rhamnosus. J. gen. Microbiol. 37, 433.

KnOX, K. W. \& HALL, E. A. (1965 a). The isolation of oligosaccharides from the cell wall polysaccharide of Lactobacillus casei, serological group C. Biochem. J. 94, 525 .

Knox, K. W. \& Hall, E. A. $(1965$ b). The linkage between the polysaccharide and mucopeptide components of the cell wall of Lactobacillus casei. Biochem. J. 96, 302.

KNox, K. W. \& Holmwood, K. J. (1968). Structure of the cell wall of lactobacilli. Role of muramic acid phosphate in Lactobacillus fermenti. Biochem. J. 108, 363.

LANCEFIELD, R. C. (I933). A serological differentiation of human and other groups of hemolytic streptococci. J. exp. Med. 57, 57I.

MCCARTY, M. (1952). The lysis of Group A hemolytic streptococci by extracellular enzymes of Streptomyces albus. I. Production and fractionation of the lytic enzymes. J. exp. Med. 96, 555.

Mirick, G. S., Thomas, L., Curnen, E. C. \& Horsfall, F. L., Jun. (1944). Immunological relationship of streptococcus MG to Streptococcus salivarius Type I. J. exp. Med. 80, 431.

Ouchterlony, O. (I953). Antigen-antibody reactions in gels. IV. Types of reaction in co-ordinated systems of diffusion. Acta path. microbiol. scand. 32, 231.

Partridge, S. M. (1948). Filter-paper partition chromatography of sugars. Biochem. J. 42, 238.

Perkins, H. R. \& Rogers, H. J. (1959). The products of the partial acid hydrolysis of the mucopeptide from cell walls of Micrococcus lysodeikticus. Biochem. J. 72, 647.

ReEs, W. R. \& ReYNolds, T. (1958). A solvent for the paper chromatographic separation of glucose and sorbitol. Nature, Lond. I81, 767.

Rondle, C. J. M. \& MORGAN, W. T. J. (1955). The determination of glucosamine and galactosamine. Biochem. J.6r, 586.

Roth, H., Segal, S. \& Bertoli, D. (1965). The quantitative determination of galactose-an enzymic method using galactose oxidase, with applications to blood and other biological fluids. Analyt. Biochem. ro, 32.

Sherman, J. M., Niven, C. F., Jun. \& Smiley, K. L. (1943). Streptococcus salivarius and other nonhemolytic streptococci of the human throat. J. Bact. 45, 249.

Shockman, G. D., KolB, J. J. \& Toennies, G. (I957). A high-speed shaker for the disruption of cells at low temperature. Biochim. biophys. Acta 24, 203.

Stewart, F. S. \& MCKeever, J. D. (1963). Serological definition of Lancefield group K. J. Path. Bact. 85, 383 .

Swift, H. F., Wilson, A. T. \& LanCefield, R. C. (1943). Typing group A hemolytic streptococci by $\mathrm{M}$ precipitin reaction in capillary pipettes. J. exp. Med. $78,127$.

Trevelyan, W. E., Procter, D. P. \& Harrison, J. S. (1950). Detection of sugars on paper chromatograms. Nature, Lond. 166, 444.

Wallenfels, K. (1950). Über einen neuen Nachweis reduzierender Zucker im Papierchromatogram und dessen quantitative Auswertung. Naturwissenschaften 37, $49 \mathrm{I}$.

Willers, J. M. M., Ottens, H. \& Michel, M. F. (1964). Immunochemical relationship between Streptococus MG, F III and Streptococcus salivarius. J. gen. Microbiol. 37, 425.

Williams, R. E. O. (1956). Stroptococcus salivarius (vel hominis) and its relation to Lancefield Group K. J. Path. Bact. 72, 15.

Williamson, C. K. (1964). Serological classification of viridans streptococci from the respiratory tract of man. In Taxonomic Biochentistry and Serology. Ed. by C. A. Leone. New York: The Ronald Press Co. 